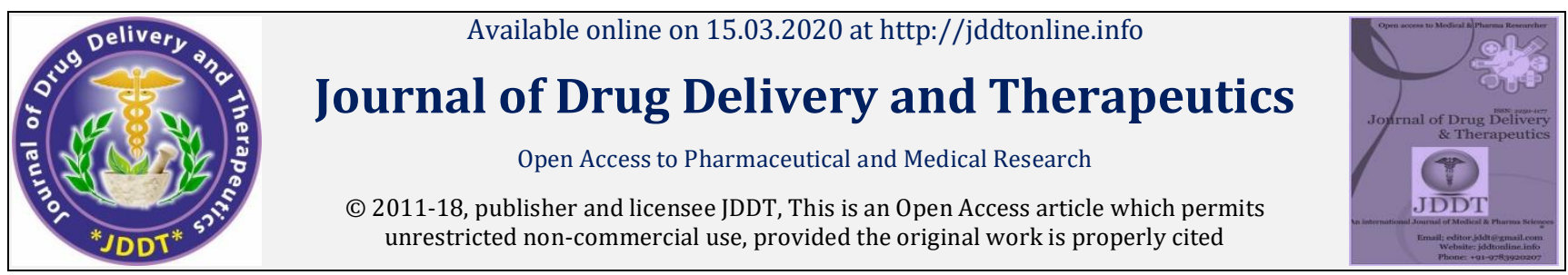

Open Access

Research Article

\title{
An Ayurveda Perspective on Khageshwar Rasa W. S. R. to Rasayogsagar
}

\author{
Swati Dongre1, Rakesh Ganvir² \\ ${ }^{1}$ Asst. Professor, Shree Ayurved Mahavidyalaya, Nagpur, India \\ ${ }^{2}$ Asst. Professor, Shri K R Pandav Ayurved College and Hospital, Nagpur, India
}

\begin{abstract}
The stream of ayurveda science that deals with therapeutics properties of minerals, precious stones, metals and poisonous herbs is termed as Rasashastra. This branch not only related with therapeutic properties of Rasaushadhies but deals with processing of Rasa-Dravyas. The Rasa drugs help to treats many diseases and imparts rejuvenating effects. The theories and principles of Rasashastra help to convert toxic substance into non-toxic life saving medicines. The process involved in the preparation in of such drugs need to be followed carefully and must be analyzed to ensure safety of formulations. Considering this current study presented various analytical aspects related to the Khageshwara Rasa.
\end{abstract}

Keywords: Ayurveda, Rasashastra, Khageshwara Rasa, Analysis

Article Info: Received 22 Dec 2019; Review Completed 10 Feb 2020; Accepted 18 Feb 2020; Available online 15 March 2020

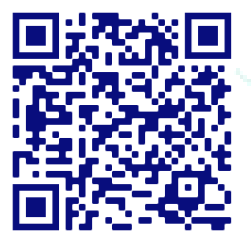

Cite this article as:

Dongre S, Ganvir R, An Ayurveda Perspective on Khageshwar Rasa W. S. R. to Rasayogsagar, Journal of Drug Delivery and Therapeutics. 2020; 10(2):42-44 http://dx.doi.org/10.22270/jddt.v10i2.3899

*Address for Correspondence:

Dr. Swati Dongre, Asst. Professor, Shree Ayurved Mahavidyalaya, Nagpur, India

\section{INTRODUCTION}

Rasashastra the important therapeutic modality of ayurveda which provides several theories and principles for the management of diseases using mineral and metal based formulations. Rasashastra mainly deals with preparations and uses of Bhasmas, Kharaliya, Pistis, Kupipakva Rasayanas, Parpati and Pottali etc. The preparations of such drugs needed uses of specific techniques like; Shodhana, Jarana and Marana, etc. These procedure converts non-consumable, toxic materials into safe and edible forms. The procedures adopted to prepare such drug must be followed as per guideline; moreover authenticity and safety of drugs must be checked through various analytical techniques which also confirm validity of procedures.

The optimization of preparatory stages is prerequisite to control quality of final product. Therefore in present study an attempt was made to perform analytical study of Khageshwara Rasa as per Ayurveda and modern science. Study aimed to authenticate quality and safety of raw materials and procedures involved in the preparation of Khageshwara Rasa. Study also establishes quality and standardization parameters for Khageshwara Rasa.

\section{MATERIALS AND METHOD}

Khageshwara Rasa prepared as per classical methods described in ancient texts of ayurveda and subjected to analytical studies as follows:

\section{Analytical study}

1. Physical analysis as per ayurveda

2. Kajjali Pariksha

3. Loss on drying

4. Total Ash

5. Acid insoluble Ash

6. Water soluble Ash

Experimental study

\section{Physical analysis as per ayurveda}

Physical analysis performed as per classical concepts of ayurveda and formulation checked for parameters such as; Shabda, Sparsha, Laghuta, Shlakshna, Rasa and Gandha, etc.

\section{\# Shabda}

Checked for metallic sound when crushed by teeth.

\section{* Sparsha}

Formulation checked for the presence of coarse particles which can be detected by touch.

\section{* Varitaratva}

Capacity of product to floats on the surface of water was investigated. 


\section{\# Nirdhuma}

Production of smoke observed when putting over the fire.

\section{* Rekhapurnatva}

Formulation was rubbed between thumb and index finger to observe properly of Rekhapurnatva.

\section{* Rasa}

Formulation tested for its tasteless property.

\section{Kajjali Pariksha}

\section{* Rekhapurnatva}

Kajjali was rubbed in between thumb and index finger to check whether it was entered the furrows of finger or not.

\section{* Varitaratva}

It should possess property of Varitaratva when puffed on the surface of water.

\section{* Nishchandratva}

Kajjali was rubbed on palm with a drop of water and was observed in bright sunlight for appearance of any shiny particle.

\section{Loss on Drying}

About 2 gm sample was dried at $105^{\circ} \mathrm{C}$ in a china dish, cooled in desiccator and weighed. Procedure repeated again until the constant weight and loss on drying was calculated as per standard formulae.

\section{Total Ash}

About 2 gm was incinerated at a temperature not exceeding $450^{\circ} \mathrm{C}$, cooled and weighed. Procedure repeat till to get constant weight and total ash value was calculated.

\section{Acid Insoluble Ash}

Ash of sample was treated with dil. HCL and insoluble matter was collected and washed with hot water then insoluble matter was transferred to original crucible dried on hot plate and ignited to constant weight, this gives percentage of acid insoluble ash.

\section{Water soluble Ash}

Ash of sample was treated with $25 \mathrm{ml}$ of water then insoluble matter was collected on filter paper, washed and ignited for 15 minutes. The subtracted value provides percentage of water soluble ash as per standard formula.

\section{RESULTS AND DISCUSSION}

The observations made during study were reported in Table 1.

Table 1: Analysis of Khageshwara Rasa

\begin{tabular}{|c|l|l|}
\hline S. No. & \multicolumn{1}{|c|}{ Parameters } & \multicolumn{1}{c|}{ Observations/results } \\
\hline 1 & Shabda & Absence of metal particles \\
\hline 2 & Sparsha & Smooth \& Shalakshna \\
\hline 3 & Rupa & Black \& Lustrous \\
\hline 4 & Gandha & Nirgandha \\
\hline 5 & Varitartva & Float on water \\
\hline 6 & Rasa & Tasteless \\
\hline 7 & Loss on drying & $1.84 \% \mathrm{w} / \mathrm{w}$ \\
\hline 8 & Total Ash & $24.25 \% \mathrm{w} / \mathrm{w}$ \\
\hline 9 & Acid insoluble Ash & $3.36 \% \mathrm{w} / \mathrm{w}$ \\
\hline 10 & Water soluble Ash & $2.37 \% \mathrm{w} / \mathrm{w}$ \\
\hline
\end{tabular}

Khageshwara Rasa is considered as Kupipakvarasayana prepared from Parada, Gandhaka and Kasisa along with Bhavana of Arjuntwakakwath. The findings of analytical study suggested following characteristics of Khageshwara Rasa:

\section{$>$ Shabda}

There were no free metal particles observed in Kajjali.

\section{$>$ Sparsha}

It indicates smoothness.

\section{$>$ Varitartva}

Study indicates low density of formulation so it can float on water.

\section{$>$ Rasa}

Tasteless; free from metallic taste as it should be like other metallic formulations.

\section{$>$ Gandha}

Formulation does not impart smell of sulphur or other metal means free from typical metallic characteristics.

The study on modern parameters indicates that it possess significant amount of ash since Total Ash Value was observed $24.25 \% \mathrm{w} / \mathrm{w}$, the component of Acid Insoluble Ash was found to be more as compared to Water Soluble Ash. Loss on drying was found below $2 \% \mathrm{w} / \mathrm{w}$ which indicates complete drying or free from moisture content which is important to restore shelf life of such formulations. 


\section{CONCLUSION}

Study observed low moisture content in Khageshwara Rasa, study concluded presence of inorganic matter in formulation since ash value observed at higher side. Acid insoluble Ash was found to be $3.36 \% \mathrm{w} / \mathrm{w}$, so it can be concluded that more than $90 \%$ drug may be absorbed in body for therapeutic action. The formulations possess most of the characteristics properties of herbo-metallic formulations since it was observed free from metal particles, possess smoothness, low density and tasteless. It does not impart smell of sulphur or other metal means free from typical metallic odour. Study concluded that these analytical studies can be used to authenticate quality of Khageshwara Rasa; however further standardization studies with validation parameters recommended to establish quality of Khageshwara Rasa.

\section{REFERENCES}

1. Sharma Sadananda. Rasa Tarangini, Edited by Kashinath Shastri. New Delhi: Motilal Banarasidas publication; 1979. 11th edition. Pp 201.

2. Wadekar MP, Patel RK, Preparation and characterization of a copper based Indian traditionaldrug: Tamra bhasma, Journal of Pharmaceutical and Biomedical Analysis, 39, 2005, 951955.
3. Acharya YT. Rasamritam, English translation by Damodar Joshi. Varanasi: Chaukhambha Sanskrit Bhawan; 1998. Pp315.

4. Lavekar, Gandhidas. Laboratory guide for the analysis of Ayurveda and Siddha formulations. New Delhi: CCRASAYUSH, Ministry of Health and F.W., Govt. of India. 2009. pp 27.

5. Kumar CS, Moorthi C, Prabu PC, Jonson DB, Venkatnarayan R. Standardization of anti-arthritic herbo-mineral preparation. Res J Pharma, Biol and Chem Sci. 2011; 2:679.

6. Vagbhata. Rasa Ratna Samucchaya, Hindi teeka by Ambika Datta Shastri. Varanasi: Choukhambha Sanskrit Bhavan; II edn: 19. Pp 61.

7. Shyama SA, Rasayana S. Rasayana Sara. 5th ed. Varanasi: Shyama Sundar Rasayanshala Prakashan; 1997.

8. Lagad CE, Sawant RS, Yelambkar P. An approach towards standardization of Swarna Makshik Bhasma (An ayurveda preparation) Int J Res Ayu Pharm. 2011; 2:723-9.

9. Shinde, Application of Quality Control Principles to Herbal Drugs, International Journal of Phytomedicine, 1, 2009. 4-8.

10. Neeli R.E, Kamta P.N and Pradeep. Standardization strategies for herbal drugs-An Overview. Res, J. Pharm. Tech.,2008; 1(4): 311-314. 